\title{
A Study of the Chinese-English Translation of Public Signs in Scenic Spots in Guangzhou From the Perspective of Skopos Theory
}

\author{
Shaohui Zheng \\ School of Foreign Studies, Guangdong University of Petrochemical Technology, Maoming, Guangdong, China
}

\begin{abstract}
Public signs, as the name card demonstrating the cultural quality and spiritual outlook of a city, play a crucial role in the external publicity of Guangzhou, an International metropolis in South China. With more and more tourists travelling to Guangzhou, the translation quality of public signs in scenic spots has become increasingly important. This paper, focusing on the public signs in scenic spots in Guangzhou, first analyzes the Chinese to English translation of public signs and finds out the translation problems and corresponding causes, and then gives some suggestions on the translation methods and strategies of the Chinese to English translation of public signs in scenic spots accordingly. It is hoped that this study can provide some implications for pedagogical application and be helpful for those who follow closely the translation of public signs.
\end{abstract}

Index Terms — public sign, scenic spot, translation strategy, Skopos rule

\section{INTRODUCTION}

China is a big country with 5000 years of civilization. With its opening up policy and the acceleration of economic globalization, more and more foreign tourists are traveling to China in pursuit of its fabulous natural circumstances and unique cultural sceneries. China is also a country with exotic customs of various ethnic groups attracting millions of foreign tourists every year. According to the National Bureau of Statistics of China (2020), tourism industry maintains steady and rapid growth every year. In 2019, the revenue of tourism industry reaches 10.94 trillion yuan, accounting for $11.05 \%$ of China's total GDP, where the number of inbound tourists was 145 million, a year-on-year increase of $2.9 \%$. In 2020, due to the COVID-19 pandemic, tourism industry all over the world suffers heavy loss. However, after China quickly controls the pandemic, tourism industry recovers soon and will grow rapidly returning to normal by 2021 . It is predicted by the Prospective Industry Research Institute (2020) that China's tourism market will continue to develop rapidly from 2021 to 2025, and the number of national tourist trips may exceed 10 billion in 2025 .

Hence, to boost tourism industry especially the inbound tourism, the translation of public signs in scenic spots is usually regarded as an indispensable element. Good translation of public signs can not only help to spread the culture bettering the humanistic environment of scenic spots, but also enhance the effect of tourism propaganda and make further improvement on tourism brands. However, the translation quality of public signs in some scenic spots in China is not satisfactory and there are various problems and insufficiencies making readers or listeners confused. Thus, it is of great significance and urgency to conduct a research on the translation of public signs in tourist attractions.

As a core city of Pearl River Delta economic zone and the Belt and Road in South China, Guangzhou attracts a large number of overseas tourists for sightseeing every year. Public signs, as the name card demonstrating the cultural quality and spiritual outlook of a city, play a crucial role in the external publicity of Guangzhou. Therefore, the translation quality of public signs in Guangzhou's scenic spots has become increasingly important. This paper, focusing on the public signs in scenic spots in Guangzhou, first analyzes the Chinese to English (C-E) translation of public signs and finds out the translation problems and corresponding causes, then gives some suggestions on the translation methods and strategies of the C-E translation of public signs accordingly. It is hoped that this study can provide some implications for pedagogical application and be helpful for those who follow closely the translation of public signs.

\section{LITERATURE REVIEW AND THEORETICAL FRAMEWORK}

\section{A. Previous Studies of the Chinese-English Translation of Public Signs}

In 2002, Beijing International Studies Universities established the first Chinese-English Public Sign Research Center in China and set up a website (www.e-signs.info.com) focusing on Chinese-English Expressions on Signs Service and Research in the next year. In 2004, Professor Hefa Lv and Liping Shan complied the Chinese-English Dictionary on Signs, which is the first reference providing abundant authentic pictures of public signs. In 2005, the first symposium on Chinese-English translation of signs was held in China, which is the most pioneering national conference in this field. From then on, lots of papers on public signs' translation appeared in academic periodicals. 
Studies on the translation of public signs abound these years at home and abroad, and lots of scholars have adopted different theories, such as Katharina Reiss's Functionalism, Ernst August Gut's Relevance Theory, Nida's principles, Newmark's Communicative Translation Theory, Ecological Translation Theory, Trichotomy, etc. while Skopos theory, which emphasizes translators' functions and expectations of target source texts, is also widely applied in analyzing the public signs translation. From the perspective of Skopos theory, strategies such as the adjustment, omission and revision can be adopted in translation, which offer good theoretical guidance for public signs' translation. (Qiu, 2013)

Previous researches study public signs from different angles. Some researchers focus on the definitions, functions and text types of public signs (See for example Dai \& Lv, 2005; Zhao \& Huang, 2015) and some study the cultural characteristics of language used (Luo \& Li, 2006). Some scholars classify different language errors and corresponding causes while some explore the regulations and standards of the translation of public signs. (See for example Ding, 2006; Yang, 2011; Lv \& Ren \& Zhou, 2015; Guo, 2018) In the early time of researches on public signs translation, scholars mainly study the application functions, linguistic styles and translation theories while in the recent 10 years, empirical researches abound and most academic papers focus on the translation of public signs especially in some cities. (See for example Zhang, 2008; Xu, 2019; Zhu \& Chen \& Lv, 2020) As China's economy develops rapidly with more foreign visitors travelling to China, the C-E public signs translation especially in scenic spots and public transportation has become increasingly important, attracting more and more researchers who have proposed corresponding translation standards and strategies. (See for example Yang, 2011; Wang, 2012; Luo \& Xu \& Shu, 2014; Chen, 2019; Chen, 2019; Tang \& Ye, 2019; Chen \& Lv, 2020) In addition, there are also many studies on the translation of public signs of different industries such as financial and medical industry. (See for example Jin, 2008; Zhu \& Li, 2011; Wang \& Yang, 2018)

However, studies focusing on public signs' translation in scenic spots in Guangzhou from the perspective of Skopos theory are scanty. How do the translators and the authorities concerned translate public signs in scenic spots by applying Skopos theory? This may provide room for the present study. This paper, focusing on the public signs in scenic spots in Guangzhou, an International city in South China, tends to explore how the three rules of Skopos theory are used in the C-E translation of public signs and give some suggestions on the translation strategies accordingly.

\section{B. An Overview of Skopos Theory}

"Skopos" refers to "purpose, intention or aim" in Greek. Skopos theory, regarded as the core of the German School of functionalist translation theory, was proposed by Hans J.Vermeer in her published book A Framework for a General Translation Theory in 1978. Vermeer defined "skopos" as the purpose of translation and based Skopos theory on the behavioral theory. From the perspective of behavioral theory, any human activity was motivated by incentive or purpose and translation is thus an activity with purposes. Different from the traditional equivalence-based translation theory, Skopos theory emphasizes the option of translation methods based on the analysis of source text with an aim to acquire the expected function of the target text. The target readers, as a decisive factor, have their specific and communicative needs, which deserves more attention. Therefore, to meet the target readers' demand by applying the Skopos theory effectively, a translator should bear in mind the reason why the original text is to be translated and the function that the target text is to acquire. (Wang, 2016) Skopos theory consists of three rules, namely Skopos rule, coherence rule and fidelity rule. According to Vermeer, the Skopos rule is regarded as the top-ranking one to which priority should be given. (Nord, 2001:29) The latter two rules are subordinate to the Skopos rule.

1. Skopos Rule

Skopos rule stresses that the translation action is determined by its "skopos", that is "the end justifies the means". Translation is considered to be a purposeful activity and the option of translation strategy depends on the translation purpose or aim of the original text. (Nord, 2001, p.29) Besides, the translation recipients with the biggest impact on the formation of the translation aim should be taken into consideration.

2. Coherence Rule

According to the coherence rule, the target text should conform to the standard of "intratextual coherence", which means the target text ought to be accessible to the target readers. (Nord, 2001, p.32) To be more specific, the target text is supposed to be coherent with the culture and communicative situation of the target readers maintaining a certain level of fluency and readability. (Wang, 2016)

3. Fidelity Rule

Vermeer holds that there exists a potential connection between the source text and target text, and he calls this relationship "intertextual coherence" or "fidelity" (Nord, 2001, p.32). Fidelity rule signifies that when people translate two different texts, the output is supposed to accord with the original meaning. Whether the content translated keeps a high consistency with the original has a close connection with the comprehension ability of translators. Fidelity rule is also inseparable from the translation purpose. To be specific, a translator is supposed to operate consciously in accordance with the purpose of the target text than the loyalty to the source text when confronted with a specific translation task. (Wang, 2016)

\section{AN OVERVIEW OF PUBLIC SignS}

Public signs are seen everywhere in our daily life and applied in various fields such as accommodation, travel, 
entertainment and shopping. As an important indicator of social environment of cities, the quality of public signs translation represents the local internationalization and human literacy. (Qiu, 2013)

\section{A. Definition of Public Signs}

According to Oxford Advanced Learner's English-Chinese Dictionary (2002, p.1406), "sign" is defined as "a piece of paper, wood or metal that has writing or a picture on it that gives you information, instruction, a warning, etc." In Longman Dictionary of Contemporary English (1995, p.1334), "sign" refers to "a piece of paper, metal, etc. in a public place, with words or drawings on it that give people information, warn them not to do something, etc." In The Merriam-Webster Dictionary (2004, p.669), "sign" means "a notice publicly displayed for advertising purposes or for giving direction or warning". In China, Professor Hefa Lv (2004) defines "public sign" as "terse and explicit words, sentences, even photographs that are closely related to daily life, production, ecology and professions so as to direct, prompt, restrict, warn, or even compel the public". As for the Chinese equivalence of "public sign", there have been lots of terms such as “标语, 标识语, 标志语, 告示语, 标牌语” while nowadays it has been standardized into “公示语”. This paper, based on the above definitions, would adopt the definition given by professor Hefa Lv and the Chinese equivalence “公示语” for the convenience of the following analysis.

\section{B. Functions of Public Signs}

Public signs play a critical role in regulating social behavior, adjusting individual relationship, enhancing mutual understanding and some other social aspects. In addition, bilingual public signs help international friends make better understanding of Chinese culture. Public signs can be formal or informal. By delivering certain kind of messages, public signs meet the social, behavioral and psychological demand of the tourists and the public. (Qiu, 2013) According to Professor Hefa Lv (2004), public signs have four functions in practical application.

1. Directing Public Signs

Directing public signs aim to provide indicative service for the public. It does not enforce people to accept some rules or warn them of potential danger, but presents the information objectively. It can provide directions such as Entrance(入 口) and Exit(出口), or sometimes with an arrow showing the readers where they are or how to get to some places. Here are some examples as follows.

TABLE 1

DiRECTING PUBLIC SignS

\begin{tabular}{|c|c|c|c|}
\hline $\begin{array}{c}\text { Source Language } \\
\text { (Chinese) }\end{array}$ & $\begin{array}{c}\text { Target Language } \\
\text { (English) }\end{array}$ & Source Language (Chinese) & $\begin{array}{c}\text { Target Language } \\
\text { (English) }\end{array}$ \\
\hline 地铁 & Underground & 货运电梯 & Sreight Lift \\
\hline 卫生间 & Restroom & 机场巴士 & Pet Hotel \\
\hline 门诊部 & Out-Patient Department & 宠物旅馆 & Men's Locker \\
\hline 游客中心 & Tourist Center & 男士更衣室 & Airport Lounges \\
\hline 综合医院 & General Hospital & 机场休息室 & 24 Hours Self-service Bank \\
\hline 咨询服务 & Consulting Service & 小时自助银行 & Sightseeeing Bus Ticket Office \\
\hline 转基因食品 & GE Food & 游览观光车售票处 & Bute \\
\hline
\end{tabular}

2. Prompting Public Signs

Prompting Public Signs are intended to give tourists some instructions to remind them of what they need to know. Their wording is terse and the mood is indirect. Examples are as follows.

TABLE 2

PROMPTING PUBLIC SIGNS

\begin{tabular}{|c|c|c|c|}
\hline $\begin{array}{c}\text { Source Language } \\
\text { (Chinese) }\end{array}$ & $\begin{array}{c}\text { Target Language } \\
\text { (English) }\end{array}$ & $\begin{array}{c}\text { Source Language } \\
\text { (Chinese) }\end{array}$ & $\begin{array}{c}\text { Target Language } \\
\text { (English) }\end{array}$ \\
\hline 售完 & Sold Out & Reserved \\
\hline 已消毒 & Sterilized & 非饮用水 & Not Drinkable \\
\hline 献血处 & Blood Donation & Beware of Dog \\
\hline 小心台阶 & Mind the Step & Minimum Charge \\
\hline 小心地滑 & Caution: Wet Floor & 不收手续费 & No Commission Charge \\
\hline 请在此等候咨询 & Here for Enquiry & 正在清扫地板 & Floor Cleaning in Progress \\
\hline 闭路电视监控区 & CCTV in Operation & Drinks Purchased Are for \\
Taken Away Only
\end{tabular}

3. Restricting Public Signs

Restricting public signs aim at playing a regulatory and confining role on the public. They are presented in a direct way. Here are some examples as follows. 
TABLE 3

RESTRICTING PUBLIC SignS

\begin{tabular}{|c|c|c|c|}
\hline $\begin{array}{c}\text { Source Language } \\
\text { (Chinese) }\end{array}$ & $\begin{array}{c}\text { Target Language } \\
\text { (English) }\end{array}$ & $\begin{array}{c}\text { Source Language } \\
\text { (Chinese) }\end{array}$ & $\begin{array}{c}\text { Target Language } \\
\text { (English) }\end{array}$ \\
\hline 现金支付 & Pay In Cash & Keep Silence \\
\hline 凭票入场 & Tickets Only & Fixed Price \\
\hline 谢绝更换 & No Exchange & 不可议价 & Disable Only \\
\hline 限停 1 小时 & 1 Hour Parking & 残疾人设施 & 热,小心㲚伤 \\
\hline 不得自带酒水 & Consumption of Our Food Only & 请系好安全带 & Please wear the seat belt provided \\
\hline $\begin{array}{c}\text { 离开前请归还 } \\
\text { 钥匙 }\end{array}$ & Please Return Keys Before Leaving & $\begin{array}{c}\text { 未经许可车辆 } \\
\text { 不得入内 }\end{array}$ & Authorized Cars Only \\
\hline $\begin{array}{c}\text { 一米以下童须家长 } \\
\text { 陪同乘坐 }\end{array}$ & $\begin{array}{c}\text { Children Under 1Meter Must be } \\
\text { Accompanied by an Adult }\end{array}$ & 来客请到门房登记 & $\begin{array}{c}\text { All Visitors Please Report to } \\
\text { Gate Warder }\end{array}$ \\
\hline
\end{tabular}

\section{Compelling Public Signs}

Compelling Public Signs aim at making the strict and fast requests on the conduct of people. It does not depend on the will of the public and is a norm that the public must abide by. People must act according to its instructions and people who go against the rules will be punished. Compelling public signs can often be seen in our daily life playing a crucial role in improving social stability and harmony, where negative words such as "No" and "Don't" are often used in English, while in Chinese the words such as “请勿” and “禁止” are mainly used. Therefore, the regulation and application of public signs are of great significance to the governments and authorities concerned. Examples are as follows.

TABLE 4

COMPELling PUBlic SignS

\begin{tabular}{|c|c|c|c|}
\hline $\begin{array}{c}\text { Source Language } \\
\text { (Chinese) }\end{array}$ & $\begin{array}{c}\text { Target Language } \\
\text { (English) }\end{array}$ & $\begin{array}{c}\text { Source Language } \\
\text { (Chinese) }\end{array}$ & $\begin{array}{c}\text { Target Language } \\
\text { (English) }\end{array}$ \\
\hline 禁止吸烟 & No Smoking & 严禁摆卖 & No Vendors \\
\hline 禁止攀爬 & No Climbing & 禁止通行 & No Photography \\
\hline 禁止张贴 & Post No Bill & 严禁拍照 & No Pets Allowed \\
\hline 禁扔废弃物 & No Littering & 禁携宠物 & Overtaking Prohibited \\
\hline 禁止导游讲解 & No Briefing of Groups & 严禁超车 & RED ROUTE No Stopping \\
警戒线内请勿超越 & Police Line Do Not Cross & 红线区内严禁停车 & Time \\
\hline
\end{tabular}

\section{Linguistic Features of Public Signs}

\section{Lexical Features}

Public signs in scenic spots are served for ordinary tourists, so their words should be clear, concise, natural and straightforward. Moreover, they should avoid using unfamiliar words, slangs or abstruse terms. Consequently, there are a number of nouns, verbs and gerunds frequently used in public signs. The first letters of those words are usually capitalized, and sometimes even all letters are capitalized to attract special attention. The specific examples are as follows:

TABLE 5

LeXicAl Features Of Public Signs

\begin{tabular}{|l|l|l|l|}
\hline $\begin{array}{l}\text { Source } \\
\text { (Chinese) }\end{array}$ & $\begin{array}{l}\text { Sanguage } \\
(\text { English) }\end{array}$ & $\begin{array}{l}\text { Target Language } \\
\text { (English) }\end{array}$ \\
\hline 收费站 & Toll Gate & 减速慢行 & Slow \\
\hline 现在营业 & Open Now & 正在施工 & Roadwork \\
\hline 注册登记 & Registration & 值班经理 & Duty Manager \\
\hline 游客止步 & STAFF ONLY & 商务中心 & Business Center \\
\hline 汽车影院 & Drive in Cinema & 外币兑换 & Foreign Exchange \\
\hline 严禁随地吐痰 & No Spitting & 严禁狗便 & No Dog Pooping \\
\hline 计时收费停车场 & Meter Parking & 野生动物保护区 & Game Reserve \\
\hline
\end{tabular}

2. Syntactic Features

In addition to the above features, public signs usually use the present tense and simple sentence patterns, including acronyms, independent words, fixed expressions, imperative sentences, phrases, etc. Examples are as follows: 
TABLE 6

SyNTACTIC Features Of PUBLIC SignS

\begin{tabular}{|l|l|l|l|}
\hline $\begin{array}{l}\text { Source Language } \\
\text { (Chinese) }\end{array}$ & $\begin{array}{l}\text { Target Language } \\
\text { (English) }\end{array}$ & Source Language (Chinese) & $\begin{array}{l}\text { Target Language } \\
\text { (English) }\end{array}$ \\
\hline 停车场 & P & 则所有人 & Occupied \\
\hline 请节约用水 & Please Save Water & 请在此排队 & Please Queue Here \\
\hline 请站好扶稳 & Please Use Handrail & 请出示证件 & Please Show Your ID \\
\hline 水深危险,请勿靠近 & Danger! Deep Water & 请勿践踏草坪 & Please Keep Off the Grass \\
\hline
\end{tabular}

\section{Discourse Features}

Terse public signs not only save people's time, but also attract people's attention. Public signs should be precise and succinct and superfluous words, such as prepositions, articles, auxiliary verbs can be eliminated. As for longish public signs, they can be used with rhetorical devices such as rhyme, repetition and antithesis, etc. Examples are as follows:

TABLE 7

Discourse Features Of Public SignS

\begin{tabular}{|c|c|}
\hline Source language (Chinese) & Target language(English) \\
\hline 请勿带宠物入内 & No Pets Allowed \\
\hline 小草青青,足下留情 & The Grass So Fair; Needs Your Care \\
\hline 别让您的烟头留下火患 & Dispose Cigarette Butts Properly \\
\hline
\end{tabular}

\section{Problems of the Chinese-English Translation of Public Signs in ScEniC Spots in GuAnGZHOU}

As an international city, Guangzhou's tourism economy is developing rapidly while lots of translation problems of public signs in scenic spots exist, including linguistic problems and pragmatic problems.

\section{A. Linguistic Problems}

\section{Spelling Mistakes}

A great amount of spelling mistakes can be found in the translation of public signs in scenic spots in Guangzhou. For example, located in the west gate of Baiyun Mountain, the bronze plaque “全国保护旅游消费者权益示范单位” is translated into "National model unit for Trotecting Tourists Rights and Interests". Here the first letters of "model unit" should be capitalized and the word "Trotecting" should be modified as "Protecting". This is a standard plaque issued by a national institution displayed in the conspicuous place, which greatly influences the image of the scenic spot. Besides, “AAAA 级旅游景区” is translated into “AAAA Class Touristry Attraction", where the "Touristry" should be "Tourist". “云台花园” is translated into “The Yuntal Garden”, where "Yuntal” should be “Yuntai”. And “草坪保养, 请勿入内” is translated as “Lawn Maintenance. Plase don’t step in". Here "Plase" should be “Please”. “严禁取水” is translated into “Don’t Dyaw Water" where "Dyaw" should be "Draw”. And “荡胸亭站” is translated as "Dang Xiong Paviling Station" where "Paviling” should be “Pavilion”. “天然鸟笼-与鸟儿逗趣的天堂” is translated into "Natural Birdcage-the Paraclise to amuse with birds", where "Paraclise" should be "Paradise". In addition, in another tourist attraction whose name on the ticket is translated into "Huang Hua Gang Mausoleum of 72 Martys", the word "Martys" should be modified as "Martyrs".

2. Capital Mistakes

Capital mistakes are prominent as well in the C-E translation of public signs in Guangzhou. Although this kind of errors will not mislead tourists as grammatical and spelling mistakes, a large number of such errors show the carelessness which will have bad influence on the urban language environment in Guangzhou. For instance, “请勿吸 烟” is translated into "No smoking" which should be modified as “No Smoking”. A public sign “中国历代书法馆” in Guangdong Museum is translated into "Gallery of Chinese calligraphy of all Dynasties" where the word "calligraphy" should be "Calligraphy". “吸烟区" is translated into "Smoking area" where "area" should be “Area". In addition, there are both spelling and capital mistakes in the sign “爱护绿化, 请勿雕刻”, which is translated into “Keep of the grass. no carving", where the word "of" should be "off" and "no carving" should be capitalized as "No Carving".

\section{B. Pragmatic Problems}

In addition to linguistic problems, there are still a lot of pragmatic problems in public signs translation in tourist attractions in Guangzhou.

1. Multiple Translations

The semantics of public signs are specific and unique. If the same public sign occurs in different places, its translation and form are supposed to be unified, or it will bring confusion, inconvenience and even misdirection to the foreign visitors. The phenomenon of non-standard translation such as non-uniform translation and multiple translation of one name is common in public signs translation in Guangzhou. The word “则所” has several different translation versions in Guangzhou, such as "WC", "Toilet", "Men \& Women” and "Male \& Female”. “广州大道” is translated into 
“Guangzhou Dadao", while “三元里大道” is translated into "San Yuan Li Avenue”. In addition, there are various English versions of the public sign “白云山风景名胜管理区” on billboards, notices and tourist guides all over the scenic spot. The translation "The Baiyun Mountain Scenic Area Bureau” which is comparatively standard is adopted by the majority while there are many other English translation versions reserving its first half and omitting the "Scenic Area Bureau" or "Bureau". However, as an administrative authority of Baiyun Mountain, its name should be kept serious and unified in every spot instead of changing arbitrarily. Besides, eight famous scenic spots in Guangzhou attract lots of foreign visitors and Guangzhou government officially calls these spots “新世纪羊城八景”. However, there are two different translation versions of “新世纪羊城八景”, i.e. “Guangzhou New-century Top Eight Scenic Spots" and "NEW CENTURY EIGHT SENCE IN GUANGZHOU”. This might mislead visitors making them confused. Professor Huikang Jin (2003) used to give suggestions on the translation of “羊城八景” as “Famous Eight of Guangzhou City”. Therefore, “新世纪羊城八景” can be modified as “Famous Eight of Guangzhou City in the $21^{\text {st }}$ Century".

2. Chinglish

Chinglish is a special kind of English created by people who are influenced by Chinese way of thinking and cultural background. It is not consistent with the native way of English expression and cannot be understood by most foreigners. However, Chinglish in scenic spots in Guangzhou abound. For example, a public sign “严禁以下活动” from Liu Hua Lake Park is translated into "PROHIBIT FOLLOWING ACTIVITIES". This kind of translation is too rigid and the suggested version is "THE FOLLOWING ACTIVITIES ARE PROHIBITED". For another example, a sign placed outside the cultural relics exhibition hall “请勿入内” in Chen Clan Ancestral Hall is translated into "No Visiting Please". This is a restricting public sign which means visitors can only stand outside the guardrail and cannot enter. However, the tourists are coming here for visiting and thus the word "Visiting" used here is inappropriate. The suggested version is "No Entry”. The same is true of this sign “即购即入, 一人一票”, which is translated into “ONE TICKEY FOR ONE TOURIST. YOU CAN ENTER ONCE YOU BUY IT”. The suggested modification is “TICKEY ONLY”. Besides, in the scenic spot Yuexiu Park, the sign “百步梯” is translated into “ONE HUNDRED LADDERS”, which is quite misleading. Visitors are confused and wonder where one hundred ladders are. In fact, there are not only one hundred steps and the suggested translation is "Hundreds-of-Steps Ladders".

\section{Causes of Translation Problems in Scenic Spots}

From the above analysis, it is found that the translators and the tourism authorities concerned should be responsible for the existing problems in public signs translation in Guangzhou's scenic spots. Translators play a crucial role in the quality of public signs translation. First, translators should have a good mastery of both English and Chinese. From the errors analyzed above, strong bilingual competence of translators can help reduce lots of linguistic and pragmatic mistakes. Second, translators should be always culturally aware of the language used in public signs as language is the carrier of culture and translation is a cross-culture activity. Therefore, translators should understand the source text accurately in grammar and appropriately in culture so as to present the target text in conformity with the language environment of the target readers. Third, translators should have strong sense of responsibility in the process of translation. As can be seen above, lots of grammatical and pragmatic problems can be avoided if the translators are more careful, serious and responsible in attitude.

In addition, the tourism authorities concerned should shoulder the responsibility as well. The standards and regulations for local public signs translation released by the government can provide good reference and better help translators and organizations in the process of translation. Luckily, today many cities in China such as Shanghai and Beijing serve as good examples in regulating public signs translation. Besides, the translation of public signs can be listed in the service assessment item of tourist attractions and professionals can be invited to make evaluation. It is also suggested that college teachers and students, media and the public be encouraged to find and correct the translation mistakes and make advices for the public signs translation in scenic spots.

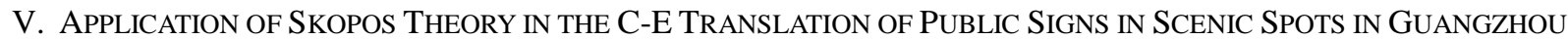

Skopos theory lays stress on the communicative functions of target texts as well as the reaction of target language readers, which is consistent with the purpose of public signs translation, i.e., to convey basic and necessary information to the public. Therefore, Skopos theory can better serve as the theoretical foundation for public signs translation.

\section{A. Simplification under the Skopos Rule}

According to the Skopos rule, the main purpose of public signs translation is to make the target readers completely understand the main message conveyed by the source language. Consequently, when translators translate public signs whose language used should be concise, some non-core words in public signs that do not affect the expression of meaning can be omitted, such as articles, conjunctions, etc., and reserving the core words that can clearly express meaning, such as nouns, verbs and other substantive words. Thus, the language used in public signs can be simplified, which means the method of simplification is suggested in translating public signs in tourist attractions. For example, “购票中请当场清点票款, 门票售出, 恕不退款” can be translated into “Check the change before you leave. No refund 
for tickets sold”. “即购即入，每人一票” is translated into “TICKEY ONLY”. In addition to the key words, the abbreviations can also be applied to simplification translation. Abbreviations are one of the most concise and understandable ways of expression. Public signs of some common public facilities and service areas in tourist attractions can be displayed by abbreviations, such as $\mathrm{E}($ 东), S(南), W(西), N(北), P(停车场), WC(则所), RD(路), etc.

\section{B. Borrowing under the Fidelity Rule}

Chinese and English are quite different languages but sometimes they share similar functions. Hefa Lv (2004, p.40) holds that because of the stringent standard, normalization and pertinence, the C-E translation of public signs should use the signs with the same function to have a one-to-one translation in both Chinese and English cultures. Besides, under the guidance of the fidelity rule, the translation is required to be faithful to the source text and the degree and form of faithfulness are determined by the translation purpose and the translator's understanding of the source text. Thus, in terms of the corresponding function and fidelity rule, the strategy of borrowing can be adopted in the public signs translation, which means expressions with equal function and consistent significance from English can be borrowed directly in translating Chinese public signs. For instance, “不可回收垃圾” can be translated into “Non-recyclable”, “售 票处” can be translated into “Ticket Office” and “禁止抽烟” can be “No Smoking”. In addition, public signs such as “请勿入内”，“游客止步” and “闲人免进”which share the same meaning and function can be translated into “No Entry" or "Staff Only", appropriately indicating that visitors are not allowed to enter. Through borrowing the native English expression, the translation will not only meet the needs of the readers, but also achieve the purpose of communication. Therefore, the method of borrowing is not only in line with the fidelity rule but also conforms to the skopos rule.

\section{Adaption under the Coherence Rule}

Translation is a cross-culture activity and thus the differences between Chinese and Western cultures should be taken into account in the process of public signs translation. However, differences of people's daily behaviors, ways of thinking and understanding of the same thing can be embodied in both Chinese and English expressions. For example, Chinese people are more indirect while Westerners are more straightforward. The Skopos rule holds that translators should adopt different translation strategies according to the intended purposes of the target texts. And the coherence rule stresses that the translated text should conform to the usual way of expression of the target language, understood and accepted by the target readers with different cultural backgrounds so as to achieve the communicative function. Therefore, according to the way of expression and cultural background of the target readers, a proper adaption can be adopted in public signs translation, which is also in accord with Skopos rule and coherence rule. For example, the literary signs in the scenic spots “心触一方净土, 爱博一片蓝天” can be translated directly into “Keep the environment clean”. In this way, the effective information is conveyed to foreign tourists. The same is true of the sign “绿色是生命 的象征, 爱护是文明的体现”. It is translated into “Green is the symbol of life. Care is the manifestation of civilization” which is quite redundant in English. The suggested version is "Please keep the environment clean" as the above example. In addition, if the sign “小草正睡觉，请勿打扰” is translated directly into “The Grass Is Sleeping, Please Don't Interrupt", the foreign tourists may be puzzled and confused. Consequently, according to the coherence rule, adaption can be adopted and this sign can be translated into "Keep Off the Grass", which is more in line with English way of expression.

\section{CONCLUSION}

As one of the leading metropolises in China, the tourism industry in Guangzhou has maintained sustainable development. Public signs play an essential role in promoting tourism economy and spreading tourism culture. However, there are still a lot of problems in the translation of public signs in scenic spots and Guangzhou is no exception. This study, by gathering a great many examples of public signs in major scenic spots in Guangzhou, makes detailed analysis of the translation from the linguistic and pragmatic aspects and finds that translators and the authorities concerned are both responsible for the translation quality of public signs. Translators should have strong bilingual competence and strong sense of responsibility. Besides, they should be culturally aware of both source and target languages used in public signs in the translation process. The authorities concerned at the same time should take some measures in regulating and standardizing the public signs translation. Additionally, more scholars, experts, teachers, students and even Guangzhou's citizens can be encouraged to find, correct the mistakes and make advices for the public signs translation. It is also found that Skopos theory is practicable and useful in the C-E translation of public signs, which lays stress on the response of target readers and holds that the communicative purpose should always take priority while public sign is a kind of text for communicative aims. Consequently, it is feasible to apply Skopos theory in the C-E translation of public signs in scenic spots in Guangzhou. To conclude, this paper, briefly introducing the public signs and Skopos theory, which offers the theoretical guidance for the C-E translation of public signs, has made a further exploration on the translation problems presented in scenic spots in Guangzhou. By giving some suggested C-E translation methods and strategies, it is hoped that this study can provide some implications for pedagogical application and be helpful for those who follow closely public signs' translation. 


\section{ACKNOWLEDGEMENTS}

This study is supported by Maoming Social Sciences Association Grant (grant number: 2019YB09) and Department of Science and Technology of Maoming (grant number: 2019431)

\section{REFERENCES}

[1] Chen Jun, Lv Hefa. (2020). Strategies for Translating Traditional Chinese Concepts in Museum Interpretations-A Cast Study of Famous Museums in USA and UK. Chinese Science \& Technology Translators Journal,1, 33-36.

[2] Chen Shunyi. (2018). Normalization of Translation of Rail Transit Public Signs. Journal of Foshan University, 4, 82-90.

[3] Chen Shunyi. (2019). Borrowing, Imitative and Creative Translations: A Practical Approach to Translation of Rail Transit Public Signs: Study on English Translations of Public Signs at Guangzhou Metro by Modeling on Rail Transit Public Signs in Main English-speaking Countries. Journal of Xichang University, 4, 83-88.

[4] Chen Shunyi.(2019). Equivalence of Politeness in Translation of Rail Transit Signs: A Study of English Translation of Guangzhou Metro Signs. Journal of Xihua University, 4, 24-28.

[5] Chen Shunyi. (2019). Procedures and Path for Translation of Rail Transit Public Signs. Journal of Zhaotong University, 1, 86-90

[6] Dai Zongxian, Lv Hefa. (2005). On C-E Translation of Public Signs. Chinese Translators Journal, 6, 38-42.

[7] Ding Henqi. (2006). Improve the City Public Signs and Gradually Determine the Reference Translation. Chinese Translators Journal, 6, 42-46.

[8] Guo Cong. (2018). A Study of the Standardization of Public Sign Translation and Quality Assurance Process. Chinese Science \& Technology Translators Journal, 1, 42-45.

[9] Jin Huikang. (2003). A Discussion on Guangdong Tourism Translation. Shanghai Journal of Translators for Science and Technology, 2, 20-24.

[10] Jin Qibin. (2008). Investigation and Analysis of the Status Quo of English Translation of Public Signs in the Medical and Health Industry. Chinese Translators Journal, 3, 72-76.

[11] Longman Dictionary of Contemporary English. (1995). Beijing: Foreign Language Teaching and Research Press.

[12] Luo Jiansheng, Li Minjie. (2015). A Study on the English Translation of Public Signs of Tourist Attractions in Western Ethnic Regions under the Guidance of Variation Translation Theory. Journal of South-Central University for Nationalities, 3, 168-171.

[13] Luo Jiansheng, Xu Ju, Shu Jing. (2014). Investigation on the English Translation of Public signs in Tourist Attractions in the Western Region. Journal of South-Central University for Nationalities, 3, 166-171.

[14] Luo Xuanmin, Li Tuwang. (2006). Translating Public Signs: Some Observations. Chinese Translators Journal, 4 , 66-69.

[15] Lv Hefa. (2004). The Chinese-English Translation of Public Signs. Chinese Science \& Technology Translators Journal, 1, $38-40$.

[16] Lv Hefa, Ren Linjing, Zhou Yanqun. (2015). A Study of Effective Approaches to the Standardization of C-E Translation of Signs. Standard Science, 10, 22-27.

[17] Lv Hefa, Shan Liping. (2004). A Chinese-English Dictionary on Signs. Beijing: The Commercial Press.

[18] Newmark P.(2001). A Textbook of Translation. Shanghai: Shanghai Foreign Language Education Press, 19-21.

[19] Nida, Eugene A. and Charles Taber. (1969). The Theory and Practice of Translation. Netherlands: Lei-den Brill.

[20] Nord, Christiane. (2001).Translating as a Purposeful Activity: Functionalist Approaches Explained. Shanghai: Shanghai Foreign Language Education Press.

[21] Oxford Advanced Learner's English-Chinese Dictionary. (2002). Beijing: The Commercial Press.

[22] Qiu Liyuan. (2013). A Study of Chinglish in Translation of Public Signs from the Perspective of Skopos Theory. Master's Thesis, Jinlin University.

[23] Reiss, Katharina. (2000). Translation Criticism: Potential and Limitations. Manchester: St. Jerome and American Bible Society.

[24] Tang Jingan, Yu Yezi. (2019). A Cognitive Study on the English Translation of Public Signs in Tourist Attractions. Chinese Science and Technology Translators Journal, 3, 50-52.

[25] The Merriam-Webster Dictionary. (2004). Springfield: Merriam-Webster Inc.

[26] The National Bureau of Statistics of China. (2020). Statistical Communiqué of the People's Republic of China on the 2019 National Economic and Social Development. http://www.stats.gov.cn/tjsj/zxfb/202002/t20200228_1728913.html. (accessed 20/1/2021)

[27] The Prospective Industry Research Institute. (2020). China's Tourism Industry Market Outlook and Investment Strategy Planning Analysis Report. https://bg.qianzhan.com/trends/detail/506/200407-b4a46701.html. (accessed 20/1/2021)

[28] Vermeer, Hans J. (1978). A Framework for a General Translation Theory. Heidelberg: Heidelberg University.

[29] Wang Chang, Yang Yuchen. (2018). Text Types and Countermeasures for English Translation of Public Signs in TCM Hospitals from the Perspective of Eco-Translation. Shanghai Journal of Translators, 4, 39-43.

[30] Wang Shuhuai. (2012). Metro Sign Translation: Problems and Principles. Shanghai Journal of Translators, 3, 30-33.

[31] Wang Shuhuai. (2014). Examples of Mistranslation of International Public Signs. Shanghai Journal of Translators, 1, $20-23$.

[32] Wang Zijun. (2016). A Study of C-E Translation of Public Signs in Major Scenic Spots in Kunming in the Light of Skopos Theory. Master's Thesis, Yunnan University.

[33] Xu Min. (2019). Text Types and Countermeasures for English Translation of Public Signs. Chinese Science \& Technology Translators Journal, 2, 48-51.

[34] Yang Hongying. (2011). A Study of the Standardization of Tourist Attractions Translation. Chinese Translators Journal, 4, 64-68

[35] Yu Jialiu. (2016). Chinese-English Translation of Public Signs in Scenic Spots of Kaifeng from the Perspective of Skopos Theory. Master's Thesis, Beijing Foreign Studies University.

[36] Zhang Meifang. (2006). Investigating the Languages and Translations of Public Notices in Macao. Shanghai Journal of 
Translators, 1, 29-34.

[37] Zhao Nan, Huang Zhonglian. (2015). Investigation and Determination of the English Translation of "Public Signs". Chinese Science and Technology Translators Journal, 3, 60-63

[38] Zhu Huifen, Chen Jun, Lv Hefa. (2020). Public Signs Translation under a Theory of Trichotomy. Shanghai Journal of Translators, 1, 20-24.

[39] Zhu Huifen, Li Yi. (2011). Investigation and Research on the Translation of Bank Signs. Zhejiang Finance, 3, 49-51.

Shaohui Zheng is a lecturer of School of Foreign Studies, Guangdong University of Petrochemical Technology. She graduated from Guangdong University of Foreign Studies and got her master's degree in 2008. Her areas of specialization include applied linguistics, intercultural communication and translation. 